J. Perinat. Med. $16(1988) 459$

\title{
Anemia, ferritin and preterm labor
}

\author{
Hans Ulrich Ulmer and Eckhard Goepel \\ Department of Gynecology and Obstetrics, University-Hospital, Hamburg, West \\ Germany
}

\section{Introduction}

Anemia at the end of gestation is a common occurrence among women in the Western world, the percentages reported in the literature varying from 20 to 60 per cent. More than $90 \%$ of anemias result from iron deficiency $[7,16]$. Schifman [25] reported that the incidence of iron depletion steadily increases from 22 to 46 per cent between the first and third trimesters of pregnancy. HEINRICH [13] stated that nearly 100 per cent of the pregnant women examined had depleted iron stores, i. e. prelatent or latent iron deficiencies. The pertinent reports in the literature differ greatly. Anemias are usually classified according to their hemoglobin levels [6]:

mild anemia with $\mathrm{Hb}$ values between 11 and 11.9 $\mathrm{g} / \mathrm{dl}$, moderate anemia with $\mathrm{Hb}$ values between 9 and $10.9 \mathrm{~g} / \mathrm{dl}$ and severe anemia with $\mathrm{a} \mathrm{Hb}$ value of less than $9 \mathrm{~g} / \mathrm{dl}$. On closer examination this structured division is not without problems. The definition of a normal range may be useful for judging a total population, its value for the individual must be questioned, especially as it fails to account for possible pathogenetic causes. Among pregnant women as a whole, anemia results from iron deficiency in more than $90 \%$ of cases. This cannot be transferred to the individual woman without qualification.

It has to be emphasized that the hemoglobin value, if taken as the only parameter, does not provide sufficient information, especially as iron deficiencies by no means regularly coincide with low hemoglobin values [26, 17]. There is a broad consensus in the literature on serum ferritin being a reliable index of iron deficiency $[17,15]$, and one that is easy to determine in the daily routine. The concentration of serum ferritin indicates the state

\section{Curriculum vitae}

Hans Ulrich UlmeR, M.D. was born in 1947. He majored in mathematics and physics and subsequently studied medicine in Innsbruck, Austria and Tübingen, W.-Germany. In 1980 he was awarded his M.D. Since 1980 he has been a member of the staff of the Department of Gynecology and Obstetrics at Ham-

burg, University Hospital (Director: Prof. H. Maass, M.D.). His fields of interest are gynecologic oncology and specific areas of obstetrics such as anemia and preterm labor.

of the iron reserves that are mainly stored as ferrritin in the liver and in the reticulohistiocytary system. $1 \mu \mathrm{g} / \mathrm{l}$ of ferritin represents $8 \mu \mathrm{g}$ of stored iron [19]. As opposed to this the still widely favored serum iron determination does not provide sufficient information on the actual iron stores in the body, as it depends on absorption in and release from the stores $[4,18]$. The risks attributed to anemia or severe iron deficiency in pregnant women are a higher disposition to infections, as well as a greater proneness to pyelonephritis [9, $3]$, pre-eclampsia $[2,11]$ and puerperal fever [8]. A higher incidence of preterm labor in pregnant women with low serum ferritin levels has been reported on only recently $[28,10]$. Potential complications for the fetus are abortion and preterm delivery $[9,11,16]$. In this context attention is drawn to correlations between low hematocrit levels and increased risk of preterm birth [20]. 
One aim of the present paper is to show in a prospective study that the estimation of hemoglobin $(\mathrm{Hb})$ and of mean corpuscular hemoglobin $(\mathrm{MCH})$, the commonly determined laboratory parameters, is inadequate to diagnose pregnancy related anemia. For this reason serum ferritin was additionally estimated in the respective pregnant women. By retrospectively evaluating the course of gestation, we were able to assess the clinical value that can actually be attributed to the estimated parameters of $\mathrm{Hb}, \mathrm{MCH}$ and serum ferritin. Our main focus of interest was to re-evaluate the correlation between preterm labor and serum ferritin levels previously reported from a smaller sample of women [10].

\section{Materials and methods}

A total of 300 women in their final stages of pregnancy ( 72 between the 28 and 35 th week, 31 in the 36th week and 197 between the 37 and 41 th week of gestation) was randomly selected from the general population of pregnant women under observation at the Department of Gynecology and Obstetrics, Hamburg University Hospital, a clinic with an above average share of high-risk pregnancies.

Women with multiple pregnancy and ascertained fetal malformations were excluded from the study. Of the 300 women, 103 (34.3 per cent) went into preterm labor before the 37 th week of gestation, and only those with regular labor substantiated by menas of cardiotocogram were included in this group. Seventy-two patients of these ( 24 per cent of the total) received oral or parenteral tocolytic treatment. As there was no danger of respiratory distress syndrome for the other 31 fetuses, the mothers did not require any tocolytic treatment.

Fifteen women suffered from gestosis with a gestosis index [5] ranging between 4 and 9. Eight patients suffered from placental insufficiency diagnosed by low levels of placenta lactogen and estriol as well as by fetal ultrasonic biometry. Nine women had a combination of both. Fourteen women were suffering from an infection of the urinary tract requiring treatment with a germ count of more than $10^{5} / \mathrm{ml}$ urine.

The hematological profiles of the 300 women were determined by the parameters $\mathrm{Hb}$ and $\mathrm{MCH}$ and examined for their relevance in diagnosing iron deficiency by comparing them with the simultaneously determined serum ferritin values. The as- certained laboratory parameters were then evaluated in retrospect focussing on the clinical parameters such as the course of pregnancy, incidence of preterm labor, preeclampsia, infections of the urinary tract, and placental insufficiency.

The parameters of the hematological profile were determined in our routine laboratory immediately after venipuncture. The estimation of serum ferritin values was carried out with blood collected in EDTA tubes and analyzed using the Enzym test (BOEHRINGER, Mannheim). The estimation and determination of the marginal values of the parameters was based on the results of our own investigations [24] which correspond to the respective values found in the literature [12]. Our classification of the different degrees is specified above. It corresponds to that of GöLTNER [9] and the WHO Technical Report [30]. In estimating the mean corpuscular hemoglobin $(\mathrm{MCH})$, values below 26.5 pg were regarded as pathological, and values between 26.5 and $28 \mathrm{pg}$ as threshold values.

The normal range of serum ferritin was assumed to be between 20 and $120 \mu \mathrm{g} / 1$ in accordance with our own investigations of a large sample. These values are in agreement with those ascertained in a survey of literature [12]. In our evaluation we differentiated ranges between 10 and $19.9 \mu \mathrm{g} / 1$ and below $10 \mu \mathrm{g} / 1$.

Values are expressed as mean \pm SD. The significance of the difference between means was calculated by the students t-test. The significance of the correlation between variables was determined by multiple regression.

\section{Results}

Of the 300 women examined,

- $46(15.3 \%)$ had an $\mathrm{Hb}$ level $\geq 12 \mathrm{~g} / \mathrm{dl}(12.87$

$\pm 0.67)$, an $\mathrm{MCH}$ value $\geq 28 \mathrm{pg}$ and a serum ferritin value $\geq 20 \mu / 1(53.78 \pm 31.41)$

- $66(22 \%)$ had an Hb level $\geq 12 \mathrm{~g} / \mathrm{dl}(12.77$ $\pm 0.61)$, an $\mathrm{MCH}$ value $>28 \mathrm{pg}$, and a serum ferritin value $<20 \mu \mathrm{gl}(10.72 \pm 4.97)$

- $58(19.3 \%)$ had an Hb level $<12 \mathrm{~g} / \mathrm{dl}(10.87$ $\pm 0.88)$, and a serum ferritin value $\geq 20 \mu \mathrm{g} / 1$ $(48.28 \pm 32.78)$

- $65(\overline{21} .7 \%)$ had an $\mathrm{Hb}$ level $<12 \mathrm{~g} / \mathrm{dl}(10.96$ $\pm 0.83)$, an $\mathrm{MCH}$ value $\geq 28 \mathrm{pg}$, and a serum ferritin value $<20 \mu \mathrm{gl}(9.29 \pm 4.75)$

$-114(38.0 \%)$ had an Hb level $<12 \mathrm{~g} / \mathrm{dl}(10.48$ $\pm 0.61)$ and a serum ferritin $<20 \mu \mathrm{g} / 1(8.91$ $\pm 4.4)$. 
Table I displays the $\mathrm{Hb}$ and $\mathrm{MCH}$ values found in the 300 women examined, together with the corresponding serum ferritin values below $10 \mu \mathrm{g}$ / 1 , between 10 and $20 \mu \mathrm{g} / \mathrm{l}$ and above $20 \mu \mathrm{g} / \mathrm{l}$.

Of the 300 pregnant women examined, 103 (34.3 per cent) went into preterm labor before their 37th week of gestation. Table II shows the $\mathrm{Hb}, \mathrm{MCH}$ and serum ferritin values of the women with and without preterm labor. Figure 1 shows the women with and without preterm labor in relation to different serum ferritin levels. Table III demonstrates the respective share of women with and without preterm labor in relation to the values of the parameters examined. The values found in the 46 women with preeclampsia, placental insufficiency or a combination of both, and with infections of the urinary tract are listed in table IV.

Table I. Levels of hemoglobin $(\mathrm{Hb})$ and serum ferritin (SF) in 300 randomly selected women in the final stage of pregnancy $(\mathrm{MCH} \geq 28 \mathrm{pg}, \underline{\mathrm{MCH}<28 \mathrm{pg})}$

\begin{tabular}{lllll}
\hline $\mathrm{SF} / \mathrm{Hb}$ & $\geq 12$ & $11-11,9$ & $9-10,9$ & $<9$ \\
\hline$\geq 20$ & $42+\underline{4}$ & $22+\underline{10}$ & $15+\underline{7}$ & $2+\underline{2}$ \\
$\geq 10,<20$ & $39+\underline{5}$ & $16+\underline{8}$ & $10+\underline{10}$ & \\
$<10$ & $27+\underline{11}$ & $26+\underline{14}$ & $9+\underline{15}$ & $4+\underline{2}$ \\
\hline
\end{tabular}

\section{Discussion}

A great number of investigators regard the prophylactic administration of iron preparations during pregnancy to be justified in the face of common incidence of iron deficiency. In an ever increasing share of the women concerned, this precaution is counteracted by a general dislike to take medica-

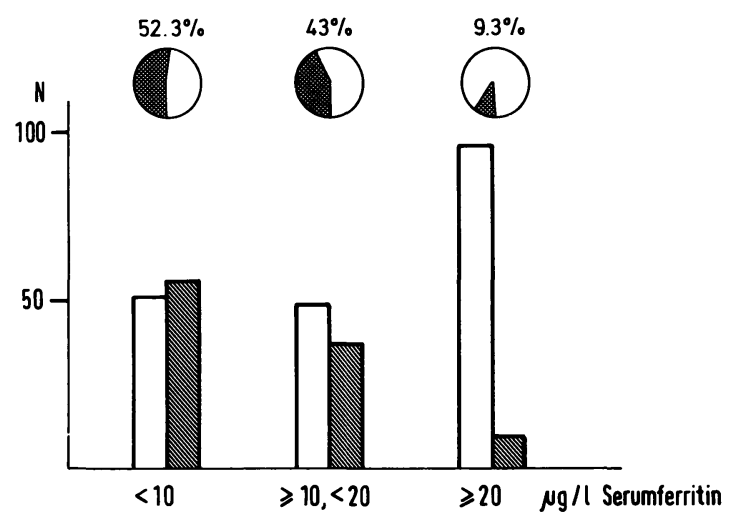

Figure 1. Number of pregnant women in relation to different serum ferritin levels. Number of patients with preterm labor. The pil chart shows the percentage of women with preterm labor.

Table II. Values of hemoglobin (Hb), $\mathrm{MCH}$ and serum ferritin in women with preterm labor

\begin{tabular}{llll}
\hline & Hb $(\mathrm{g} / \mathrm{dl})$ & $\mathrm{MCH}(\mathrm{pg})$ & ferritin $(\mu \mathrm{g} / \mathrm{l})$ \\
\hline with labor (103) & $11.43 \pm 1.18$ & $29.16 \pm 2.86$ & $12.35 \pm 12.29$ \\
without labor (197) & $11.87 \pm 1.19$ & $29.74 \pm 2.79$ & $28.23 \pm 27.92$ \\
& & & $\mathrm{p}<0.001$ \\
\hline
\end{tabular}

Table III. Number of pregnant women with and without preterm labor in relation to different $\mathrm{Hb}, \mathrm{MCH}$ and $\mathrm{SF}$ levels (means $\pm \mathrm{SD})$

\begin{tabular}{|c|c|c|c|c|}
\hline & \multicolumn{2}{|c|}{ women with labor } & \multicolumn{2}{|c|}{ women without labor } \\
\hline & number & means $\pm \mathrm{SD}$ & number & means $\pm \mathrm{SD}$ \\
\hline $\begin{array}{r}H b<9 \\
9 \leq \mathrm{Hb}<11 \\
11 \leq \mathrm{Hb}<12 \\
\mathrm{Hb} \geq 12\end{array}$ & $\begin{array}{r}5 \\
28 \\
36 \\
34\end{array}$ & $\begin{array}{r}8.74 \pm 0.14 \\
10.38 \pm 0.52 \\
11.44 \pm 0.29 \\
12.68 \pm 0.55\end{array}$ & $\begin{array}{r}5 \\
38 \\
60 \\
94\end{array}$ & $\begin{array}{c}8.10 \pm 0.5 \\
10.33 \pm 0.49 \\
11.48 \pm 0.31 \\
12.86 \pm 0.66\end{array}$ \\
\hline 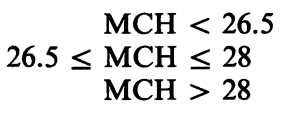 & $\begin{array}{l}20 \\
17 \\
66\end{array}$ & $\begin{array}{l}25.11 \pm 0.15 \\
27.13 \pm 0.45 \\
30.92 \pm 1.79\end{array}$ & $\begin{array}{r}21 \\
30 \\
146\end{array}$ & $\begin{array}{l}24.76 \pm 1.23 \\
27.30 \pm 0.44 \\
31.12 \pm 1.74\end{array}$ \\
\hline $\begin{array}{r}\mathrm{SF}<10 \\
\mathrm{SF}<20 \\
\mathrm{SF} \geq 20\end{array}$ & $\begin{array}{l}56 \\
37 \\
10\end{array}$ & $\begin{array}{r}6.20 \pm 2.13 \\
13.43 \pm 2.62 \\
42.83 \pm 21.04\end{array}$ & $\begin{array}{l}51 \\
49 \\
97\end{array}$ & $\begin{array}{r}5.89 \pm 2.14 \\
14.72 \pm 2.91 \\
47.05 \pm 33.26\end{array}$ \\
\hline
\end{tabular}


Table IV. Hb, MCH and serumferritin in women with preclampsia, placental insufficiency (pi) and infections of the urinary tract

\begin{tabular}{lrlll}
\hline & number & means $\pm \mathrm{SD}$ & \\
\cline { 3 - 5 } & & $\mathrm{Hb}$ & $\mathrm{MCH}$ & serum ferritin \\
\hline preclampsia & 15 & $12.46 \pm 0.91$ & $28.43 \pm 2.59$ & $22.60 \pm 19.10$ \\
pi & 8 & $12.33 \pm 0.82$ & $31.90 \pm 1.65$ & $49.30 \pm 48.70$ \\
preclampsia + pi & 9 & $12.01 \pm 0.76$ & $29.61 \pm 2.95$ & $21.32 \pm 12.40$ \\
urin. tract inf. & 14 & $11.64 \pm 1.07$ & $30.20 \pm 1.81$ & $43.31 \pm 30.27$ \\
\hline
\end{tabular}

tion, especially if the necessity to take them is not established in each individual case. NAEYE [23] found in a large prospective study that the incidence of placental infarctions correlates well with high $\mathrm{Hb}$ values in the mother. MURPHY [22] found in a study of more than 50000 pregnant women that a rising $\mathrm{Hb}$ value is associated with higher incidence of high blood pressure. Such findings raise the question of whether a routine administration of iron, as frequently recommended without actually proving iron deficiency is at all beneficial to the individual patient. The exact diagnosis of iron deficiency has been possible for several years now by means of serum ferritin estimation which correlates in a significant way with iron stores. There is still a certain discord on the lower margin of normal values. On the one hand, this results from different estimation procedures and varying animal antibodies and on the other hand from the lack of a definition of standard ferritin [29] on an international scale. Proceeding from the assumption that $1 \mu \mathrm{g} / 1$ ferritin represents about $8 \mathrm{mg}$ stored iron and that iron stores of 200 $\mathrm{mg}$ constitute prelatent iron deficiency [14], iron stores must be considered depleted with serum ferritin values below $20 \mu \mathrm{g} / 1$ [12]. The estimation of the $\mathrm{Hb}$ level, as is usually carried out during routine supervision of pregnant women, does not provide sufficient information concerning the iron stores. TAYLOR [27] reported a decline of the $\mathrm{Hb}$ value from 12.2 down to $11.4 \mathrm{~g} / \mathrm{dl}$ during pregnancy. This value is practically identical with the mean $\mathrm{Hb}$ value of our pregnant women (11.72 $\pm 1.2)$. Of the 300 women examined 146 (48.6 per cent) had an $\mathrm{Hb}$ level of over $11 \mathrm{~g} / \mathrm{dl}$ and in spite of this serum ferritin values of below $20 \mu / \mathrm{dl}$; in 78 women ( 26 per cent) serum ferritin values were even below $10 \mu \mathrm{g} / \mathrm{l}$. In 26 women (8.7 per cent) the serum ferritin value was larger than $20 \mu \mathrm{g} / \mathrm{dl}$ dispite an $\mathrm{Hb}$ level below $11 \mathrm{~g} / \mathrm{dl}$. Hb values of women with serum ferritin values above $20 \mu \mathrm{g} / \mathrm{l}$ do not vary to a clinically relevant extent from those with levels below $20 \mu \mathrm{g} / 1,(11.79 \pm 1.27)$ as opposed to $(11.68 \pm 1.16)$.

Further information can be obtained by estimating $\mathrm{MCH}$. In 108 women (36 per cent) from our sample even a combination of both parameters $\mathrm{Hb}$ values $>11 \mathrm{~g} / \mathrm{dl}$ and $\mathrm{MCH}>28 \mathrm{pg}-$ fails to give evidence of an existing iron deficiency with serum ferritin values below $20 \mu \mathrm{g} / \mathrm{l}$. On the whole, 196 of the 300 women ( 65.3 per cent) exhibited iron deficiency with values below $20 \mu \mathrm{g} / \mathrm{l}$. It is obvious that only the serum ferritin value provides reliable information on iron deficiency, whereas both the other parameters ( $\mathrm{Hb}$ and $\mathrm{MCH})$ merely do so to a limited extent. Our findings are in agreement with those of other authors [21]. Our investigations into the clinical relevance of the above mentioned parameters confirmed above all the existence of a correlation between preterm labor and low serum ferritin values. Women (52.3 per cent) with a serum ferritin value below $10 \mu \mathrm{g} /$ 1 and 43.5 per cent of the women with a serum ferritin value between 10 and $20 \mu / 1$ went into preterm labor. This was the case in only 9.5 per cent of the women with values above $20 \mu \mathrm{g} / \mathrm{l}$. The mean serum ferritin value of $12.35 \pm 12.61 \mu \mathrm{g} / 1$ in women with preterm labor is significantly lower than the value of $28.23 \pm 27.92 \mu \mathrm{g} / \mathrm{l}(\mathrm{p}<0.001)$ ascertained in women without preterm labor. As opposed to this a comparison of the other parameters does not indicate significant differences. An adequate explanation for this obvious correlation has not yet been advanced. BROTANEK's [1] hypothesis is that apart from insufficient oxygen supply to the fetus, a hypoperfusion of the placenta and, as a consequence, ischemic decidual necrosis may lead to the release of prostaglandines and thus induce labor contractions might well be one of the constituents in the multifactorial process of labor induction. This hypothesis is to a certain extent contradicted by the fact that women with low serum ferritin levels and occurrence of preterm labour contractions may well have normal 
$\mathrm{Hb}$ and $\mathrm{MCH}$ values and also a normal oxygen carrying capacity. One may assume another mechanism being effective, e.g. a deficiency in other iron containing enzymes.

Further investigations will have to determine whether iron stores can, in individual cases, be refilled during pregnancy in women with low serum ferritin levels which indicate proneness to preterm labor, and thus hopefully confirm the tocolytic effect of such treatment.

The percentage of patients with preeclampsia, placental insufficiency and infections of the urinary tract as given in table IV was too small to discover a similar correlation with iron deficiency as explained above.
In conclusion we can state that the estimation of serum ferritin is suitable for giving an exact record of iron deficiency since the parameter is independent of the physiological changes typical of gravidity, such as, for example, an increase in plasma volume. Sharing the view of other authors the present study shows that the estimation of hemoglobin - even when supplemented by other parameters of the hematological profile - is insufficient to reliably diagnose anemia. Moreover, the study shows that women with low serum ferritin values significantly more often go into preterm labor than women with normal serum ferritin values. A convincing explanation for this correlation has not yet been brought forth and further clinical research is necessary.

\begin{abstract}
The results of this study suggest that the additional determination of serum ferritin in pregnancy is necessary for a more reliable classification of iron deficiency. In 300 pregnant women the hematological values $(\mathrm{Hb}$, $\mathrm{MCH}$ and serum ferritin) were determined toward the end of gestation. In 36 per cent of the women both $\mathrm{Hb}$ values $>11 \mathrm{~g} / \mathrm{dl}$ and $\mathrm{MCH}$ values $<28 \mathrm{pg}$ fail to give evidence of an existing iron deficiency, indicated by
\end{abstract}

serum ferritin values below $20 \mu \mathrm{g} / \mathrm{l}$. The determination of serum ferritin is of particular relevance as a significant correlation was ascertained between low serum ferritin levels and the incidence of preterm labor: $52.3 \%$ of the women with serum ferritin levels below $10 \mu \mathrm{g} / \mathrm{l}$ and only $9.5 \%$ of the women with serum ferritin levels above 20 $\mu \mathrm{g} / \mathrm{l}$ went into preterm labor. A convincing explanation for this has not yet been found.

Keywords: Anemia, iron-deficiency, pregnancy, preterm labor, serum ferritin.

\section{Zusammenfassung}

\section{Anämie, Ferritin und Frühgeburt}

Gegen Ende der Schwangerschaft haben viele Frauen eine Anämie, wobei in der Literatur Zahlen zwischen 20 und $60 \%$ angegeben werden. In mehr als $90 \%$ der Fälle geht diese Anämie auf einen Eisenmangel zurück. Lediglich den $\mathrm{Hb}$-Wert zu bestimmen, reicht nicht aus, da ein Eisenmangel auch bei normalen $\mathrm{Hb}$-Werten vorliegen kann. Die Messung des Ferritinspiegels im Serum eignet sich am besten zur Diagnose eines Eisenmangels. Die Untersuchung ist relativ einfach, und in der Literatur herrscht Konsens darüber, daß sie eine verläßliche Aussage über die Eisenvorräte im Körper liefert. Zu beachten sind auch die durch eine Anämie bedingten Komplikationen, speziell die erhöhte Inzidenz von Fehl- und Frühgeburten. In einem kleinen Untersuchungskollektiv konnten wir eine signifikante Korrelation zwischen niedrigen Serumferritinspiegeln und einer erhöhten Inzidenz von Frühgeburten nachweisen. In der vorliegenden Studie sollte diese Hypothese an einem größeren Kollektiv überprüft werden. Bei 300 randomisiert ausgewählten Frauen wurden am Ende der Schwangerschaft Serumferritin, Hb-Wert und MCH bestimmt. 22\% der Frauen hatten einen Ferritinspiegel $<20 \mu \mathrm{g} / \mathrm{l}$ bei Hb-Werten $\geq 12 \mathrm{~g} / \mathrm{dl} .65 \%$ litten an einem Eisenmangel, der durch Ferritinspiegel $<20 \mu \mathrm{g} / \mathrm{l}$ angezeigt wurde. Die klinische Relevanz der untersuchten Parameter zeigt sich darin, daß 52.3\% der Frauen mit Ferritinspiegel $<10 \mu \mathrm{g} / \mathrm{l}$ Frühgeburtsbestrebungen hatten, während dies bei Ferritinspiegeln $>20 \mu \mathrm{g} / \mathrm{l}$ nur für $9.5 \%$ galt. Zur Zeit gibt es keine pathophysiologische Erklärung für diesen $\mathrm{Zu}$ sammenhang. Hinsichtlich einer Korrelation zwischen Gestose bzw. Plazentainsuffizienz und Anämie waren in unserem Kollektiv nicht genügend Fälle, um sichere Aussagen zu machen.

Schlüsselwörter: Anämie, Eisenmangel, Ferritinspiegel im Serum, Frühgeburt, Schwangerschaft. 


\section{Résumé}

\section{Anemie, ferritine et accouchement prematuré}

En fin de grossesse, un bon nombre de femmes sont anémiques, les estimations dans la littérature vont de 20 à $60 \%$. Ces anémies sont secondaires à un manque de fer dans plus de $90 \%$ des cas. Il est clair que le seul dosage de l'hémoglobine est insuffisant, car il peut exister un déficit ferrique malgré une hémoglobinémie normale. Le dosage de la férritine sérique est particulièrement approprié pour faire le diagnostic de déficit en fer. Le dosage de ferritine est relativement aisé et il existe un consensus au sein de la littérature sur le fait qu'il s'agit d'un index fiable des réserves en fer de l'organisme. En outre, les auteurs attirent l'attention sur les dangers potentiels secondaires à l'anémie, et, tout particulièrement, sur l'élévation de l'incidence des fausses-couches et de l'accouchement prématuré. Nous avons déjà trouvé une corrélation significative entre ferritinémie basse et la survenue d'accouchement prématuré dans une étude portant sur un échantillon de femmes plus petit. Cette étude a pour objectif de faire le bilan de cette corrélation sur un groupe de femmes enceintes plus important. Dans cette optique, nous avons sélectionné par randomisation 300 femmes en fin de grossesse et nous avons dosé la ferritine ainsi que l' $\mathrm{Hb}$ et le $\mathrm{MCH}$. $22 \%$ des femmes ont une ferritinémie $<20 \mu \mathrm{g} / 1$ bien que leur hémoglobine soit $\geq 12 \mathrm{~g} / \mathrm{dl}$. $65 \%$ des femmes de l'échantillon total présentent un déficit en fer indiqué par une ferritinémie $<20 \mu \mathrm{g} / \mathrm{l}$. L'étude des effets cliniques des paramètres mesurés montre que $53 \%$ des femmes avec une ferritinémie $<10 \mu \mathrm{g} / \mathrm{l}$ entrent en travail prématurément, alors que ce n'est le cas que chez $9,5 \%$ de celles qui ont une ferritinémie $>20 \mu \mathrm{g} / 1$. A l'heure actuelle, il n'existe pas d'explication physiopathologique à cette corrélation. Le nombre de femmes de cet échantillon qui ont présenté une gestose et une insuffisance placentaire est trop faible pour qu'on puisse trouver des corrélations.

Mots-clés: Accouchement prématuré, anémie, déficit en fer, ferritinémie, grossesse.

\section{References}

[1] BrotaneK V, CH Hendricks: Importance of changes in uterine blood flow in inititiation of labor. Am J Obstet Gynecol 105 (1969) 535

[2] Chaudhuri SK: Correlation of toxemia with anemia of pregnancy. Am J Obstet Gynecol 106 (1970) 254

[3] FEDE T: Urinary Tract Infection and Anemia in Pregnancy. Clin Exp Obst Gyn X (1983) 14

[4] FRICK P: Eisenmangelanämie. In: Siegenthaler W: Klinische Pathophysiologie, 4. Aufl. Georg Thieme, Stuttgart-New York 1982

[5] GILle J: Schwangerschaftsinduzierte Hypertonie. In: KÜNZEL W, K WULF (eds): Die gestörte Schwangerschaft. Urban \& Schwarzenberg, MünchenWien - Baltimore 1986

[6] Göltner E: Bedeutung des Eisenmangels in Gynäkologie und Geburtshilfe. Therapiewoche 28 (1978) 7709

[7] GöLTNER E: Hämatologische Erkrankungen in der Schwangerschaft. In: KäsER O, V FrIEDBERG, KG OBER, K ThOMSEN, J ZANDER: Gynäkologie und Geburtshilfe, Band II. Thieme, Stuttgart 1981

[8] GöLTnER E: Schwangerschaftsanämien. Therapiewoche 31 (1981) 6

[9] Göltner E: Die Bedeutung der Anämie in Gynäkologie und Geburtshilfe. Med Welt 32 (1981) 1413

[10] Goepel E, HU Ulmer, RD NeTH: Premature Labor Contractions and the Value of Serum Ferritin during Pregnancy. Gynecol Obstet Invest. 26 (1988) 265

[11] GooduIn RC: Why treat "Physiologic" Anemias of Pregnancy? J Reprod Med 27 (1982) 639
[12] Hausmann K, J Drews, R Trampe, I Wedekind, E Göltner, R Kruse, J DüllmanN: Die Serumferritinbestimmung in der Diagnostik des Eisenmangels. In: KALTWASSER JP, E WERNER: Serumferritin, Springer, Berlin 1981

[13] HEINRICH HC, H BARTELS, B HeINISCH: Intestinal 59-Fe-Resorption and prälatenter Eisenmangel während der Gravidität des Menschen. Klin Wschr 46 (1968) 199

[14] HeINRICH HC, KH OpPITZ, H BusCH: Eisenmangel und Eisenprophylaxe bei Blutspendern. Klin Wschr 51 (1973) 101

[15] HeINRICH HC: Diagnostischer Wert der Radioeisenabsorption und des Serum-Ferritins bei Eisenmangel und Eisenüberladung. Med Welt 30 (1979) 89

[16] Kaltwasser JP: Die Gefährdung der Schwangerschaft durch Anemien. Arch Gynecol VI 232 (1981) 339

[17] Kaltwasser JP: Die Bedeutung des Serumferritins für die Diagnose und Verlaufsbeobachtung des Eisenmangels. Med Welt 32 (1981) 1405

[18] KaLtWASSER JP, E WeRnER: Serumferritin als Kontrollparameter bei der Therapie des Eisenmangels. In: KALTWASSER JP, E WERNER: Serumferritin, Springer, Berlin 1981

[19] Kelly AM, MB McNaY: Ferritin as an Assessment of Iron Stores in Pregnancy. Br J Obstet Gynecol 84 (1977) 434

[20] Lieberman E, KJ Ryan, RR Monson, SC SCHOENBAUM: Risk factors accounting for racial differences in the rate of premature birth. New Engl J Med 317 (1987) 743 
[21] Linkesch W, E Pavelka, E Kofler: Serumferritin in der Gravidität: Normalverlauf, Frühgeburtsbestrebungen, EPH-Gestose. In: KALTWASSER JP, E WERNER: Serumferritin, Springer, Berlin 1981

[22] Murphy JF, RG Newcombe, J O'Riordan, EC COLES, JF PEARSON: Relation of Haemoglobin levels in first and second trimesters to outcome of pregnancy. The Lancet May 3 (1986) 992

[23] NAEYE RL: Placental imfarction leading to fetal or neonatal death. Obstet Gynecol 50 (1977) 583

[24] NeTH RD: Blutbild und Urinstatus. Springer, Berlin - Heidelberg - New York 1977

[25] Schifman RB, JE Thomasson, JM Evers: Red blood cell zinc protoporphyrin testing for irondeficiency anemia in pregnancy. Am $J$ Obstet Gynecol 157 (1987) 304

[26] Segall ML, J Dommisse, ED Du Toit, DA Davey, HVDE HeESE: Serum Ferritin Estimation in the Assessment of Iron Stores in Servere Iron Deficiency Anemia in Pregnancy and the Response to Treatment. S Afr med J 55 (1979) 287
[27] Taylor DJ, C Mallen, N McDougall, T Lind: Serum ferritin in women of reproductive age. $\mathrm{Br} \mathrm{J}$ Obstet Gynecol 89 (1982) 1000

[28] UlMER HU, E GoEPEL, RD NETH: Value of serum ferritin in the diagnosis of anemia in pregnant women. Report on the XIth World Congress of Gynecology and Obstetrics, Berlin 1985. Arch Gynecol 237 (Suppl) 1985

[29] WERNER E, JP KaltwasSer: Nachweisverfahren zur Serumferritinbestimmung. In: KaLTwASSER JP, E WERNER: Serumferritin. Springer, Berlin 1980

[30] WHO Technical Reports Seriens. Nutritional ANEMias. Report of a WHO Scientific Group. No. 4051968

Received April 28, 1988. Revised June 30, 1988. Accepted July 8, 1988.

Hans Ulrich Ulmer, M.D.

Department of Gynecology and Obstetrics University-Hospital Eppendorf,

Martinistr. 52

D-2000 Hamburg 20

West Germany 